\title{
Mediastinal germ cell tumour during the COVID-19 pandemic
}

\author{
Timothy O'Brien, Derek G Power
}

Department of Medical Oncology, Cork University Hospital Group, Cork, Ireland

Correspondence to Dr Timothy O'Brien; timothy.n.obrien@gmail.com

Accepted 2 July 2020

\section{DESCRIPTION}

A 23-year-old male accountant with no comorbidities developed a cough and dyspnoea while travelling for work in the UK during March 2020. His symptoms developed over 2 weeks and having contacted a local primary care office, he was referred to a COVID-19 test centre. A swab was not performed as he was considered to be young and in a low-risk category. He was advised to take analgesia, bed rest and self-isolate.

On returning to Ireland, he was required to selfisolate for a further 14 days. Five weeks and three negative swabs later, his symptoms deteriorated with pleuritic chest pain and a severe cough. His primary care physician requested a plain chest radiograph, which demonstrated a large mass within the right hemithorax (figure 1).

On admission to hospital, he did not require oxygen and was haemodynamically stable. A CT of the thorax, abdomen and pelvis showed a $10 \times 11 \mathrm{~cm}$ mass arising in the anterior mediastinum with marked stenosis of the superior vena cava and the pulmonary artery trunk (figure 2). No distant metastatic disease was identified confirming clinical stage II disease. ${ }^{1}$ Testicular examination and ultrasound were unremarkable. Histological evaluation of the mediastinal lesion confirmed an extragonadal germ cell tumour, of yolk sac origin, with a serum alpha-fetoprotein level of $17000 \mathrm{ng} / \mathrm{mL}(0.9-8.8$ $\mathrm{ng} / \mathrm{mL})$. Other blood tests included an elevated lactate dehydrogenase of 699 unit/L (220-450

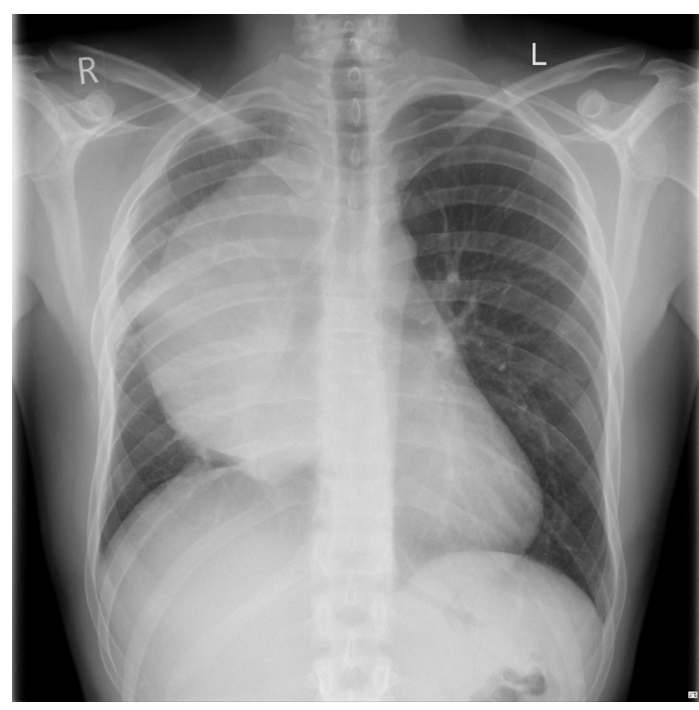

Figure 1 A plain chest radiograph demonstrating a large, well-circumscribed opacification within the right hemithorax.

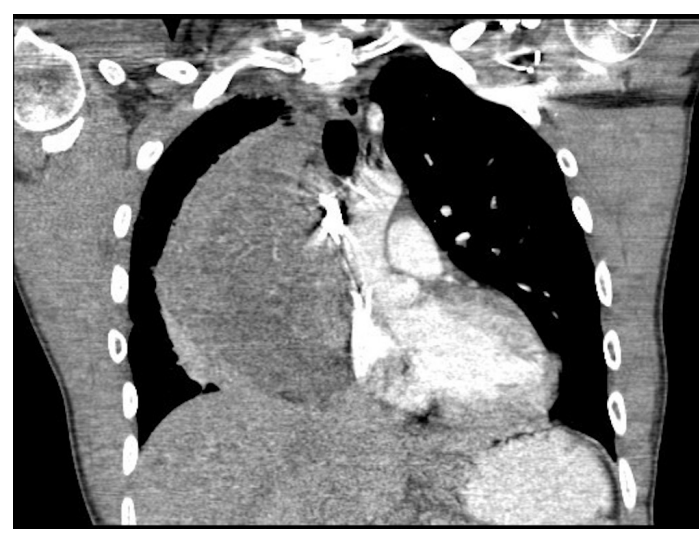

Figure 2 A coronal CT image of the thorax demonstrating a right-sided $10 \times 11 \mathrm{~cm}$ mass arising from the anterior mediastinum causing mass effect.

unit/L) and an undetectable beta-human chorionic gonadotropin ( $<1$ unit/L).

According to the International Germ Cell Cancer Consensus Group, this represented poor-risk disease due to the mediastinal origin. ${ }^{2}$ Urgent chemotherapy was commenced as an inpatient with the regimen VIP, a 21-day cycle consisting of etoposide $\left(75 \mathrm{mg} / \mathrm{m}^{2}\right.$, days $1-5)$, ifosfamide $\left(1200 \mathrm{mg} / \mathrm{m}^{2}\right.$ with mesna days $1-5)$ and cisplatin $\left(20 \mathrm{mg} / \mathrm{m}^{2}\right.$, days $\left.1-5\right)$. Pegfilgrastim was administered to reduce the risk of neutropenia. He was discharged after completing the first of four cycles. Depending on the response on conclusion

\section{Patient's perspective}

I had a continuous chesty cough, which was hard to get rid of. One month before diagnosis, I had symptoms of COVID-19, including high temperatures, severe shortness of breath and a very intense dry chesty cough. The agonising chest pain also returned at this time, which I was told was likely to be muscular pain resulting from the coughing. I appeared to have recovered from this after 2 weeks with no medical attention. I was left with shortness of breath and a cough, which got worse in the time leading up to admission and it often resulted in me vomiting just from the intensity of the cough. The cough went away within days of starting chemotherapy and I noticed a sensation which felt like some of my airways which had been impeded were opening again. I would not have had lung problems before this and would have considered myself to be quite fit. 
of chemotherapy, it is likely he will require surgery to resect any residual disease.

Extragonadal germ cell tumours are rare and carry a worse prognosis than those of testicular origin. ${ }^{3}$ Regarding pathogenesis, it is not known whether they represent primordial germ cells that failed to migrate to the testis during embryogenesis or if, in fact, they are germ cells that undergo reverse migration from the testis.

Our case also highlights a concern regarding the deprioritisation of certain healthcare services during the COVID-19 pandemic. ${ }^{4}$ Delayed cancer diagnoses may result in increased

\section{Learning points}

- From virtual clinics to social distancing, the COVID-19 pandemic has radically changed the way we practice medicine and in the midst of this change, we must retain a sound medical judgement and remember that 'it is not always COVID-19'.

- Cancer diagnoses are likely to be delayed during the COVID-19 pandemic leading to more advanced disease at presentation. cancer-related mortality and increased demand on an already stretched healthcare service.

Contributors TOB wrote the manuscript. DGP edited the manuscript.

Funding The authors have not declared a specific grant for this research from any funding agency in the public, commercial or not-for-profit sectors.

Competing interests None declared.

Patient consent for publication Obtained.

Provenance and peer review Not commissioned; externally peer reviewed.

This article is made freely available for use in accordance with BMJ's website terms and conditions for the duration of the covid-19 pandemic or until otherwise determined by BMJ. You may use, download and print the article for any lawful, non-commercial purpose (including text and data mining) provided that all copyright notices and trade marks are retained.

\section{REFERENCES}

1 Moran CA, Suster S. Primary germ cell tumors of the mediastinum: I. Analysis of 322 cases with special emphasis on Teratomatous lesions and a proposal for histopathologic classification and clinical staging. Cancer 1997;80:681-90.

2 International germ cell consensus classification: a prognostic factor-based staging system for metastatic germ cell cancers. International germ cell cancer Collaborative group. J Clin Oncol 1997;15:594-603.

3 Rosti G, Secondino S, Necchi A, et al. Primary mediastinal germ cell tumors. Semin Oncol 2019:46:107-11.

4 The Lancet Oncology. Safeguarding cancer care in a post-COVID-19 world. Lancet Oncol 2020:21:603.

Copyright 2020 BMJ Publishing Group. All rights reserved. For permission to reuse any of this content visit

https://www.bmj.com/company/products-services/rights-and-licensing/permissions/

BMJ Case Report Fellows may re-use this article for personal use and teaching without any further permission.

Become a Fellow of BMJ Case Reports today and you can:

- Submit as many cases as you like

- Enjoy fast sympathetic peer review and rapid publication of accepted articles

- Access all the published articles

- Re-use any of the published material for personal use and teaching without further permission

\section{Customer Service}

If you have any further queries about your subscription, please contact our customer services team on +44 (0) 2071111105 or via email at support@bmj.com.

Visit casereports.bmj.com for more articles like this and to become a Fellow 